\title{
Mycoherbicide associated with the leaf spot of Chenopodium album L.
}

\author{
Micoherbicida asociado a la mancha foliar de \\ Chenopodium album L.
}

\author{
Abiel Sánchez-Arizpe; Ma. Elizabeth Galindo-Cepeda; José Luis Arispe-Vázquez* \\ Departamento de Parasitología, Universidad Autónoma Agraria Antonio Narro, Antonio Narro \#1923, C.P. 25315, \\ Buenavista, Saltillo, Coahuila, México. \\ *Autor corresponsal: arispe_uaaan@hotmail.com (J.L. Arispe-Vázquez). \\ ID ORCID de los autores \\ A. Sánchez-Arizpe: (iD http://orcid.org/0000-0001-9684-4950 \\ Ma.E. Galido-Cepeda: iD http://orcid.org/0000-0003-3715-8605 \\ J.L. Arispe-Vázquez: (iD http://orcid.org/0000-0003-1357-2238
}

\section{ABSTRACT}

The objective this research was identify the fungi associated with the Chenopodium album leaf spot. Samplings were carried out at Universidad Autonoma Agraria Antonio Narro in a manner directed towards the weeds (10 plants) that showed signs and symptoms of this disease (pycnidia and a yellow halo on the leaves) and were later taken to the phytopathology laboratory for isolation and identification. The weed identified by morphological criteria. Pathogen was identified by morphocultural of 100 conidia criteria using AxioVision Release 4.5 software. The purification of the isolates was performed by hypha tip in PDA. Macrophoma sp. was identified damaging the weed C. album whit conidia ellipsoidal to subglobose, of $18.21 \mu \mathrm{m}$ length and $2.56 \mu \mathrm{m}$ width. Therefore a future investigation of this pathogen and host is recommended.

Keywords: weed; fungi; leaf spot; conidia; mycoherbicide.

\section{RESUMEN}

El objetivo de esta investigación fue identificar los hongos asociados con la mancha foliar de Chenopodium album. Los muestreos se realizaron en la Universidad Autónoma Agraria Antonio Narro de manera dirigida hacia las malezas (10 plantas) que presentaban signos y síntomas de esta enfermedad (picnidios y un halo amarillo en las hojas) y posteriormente fueron trasladados al laboratorio de fitopatología para su aislamiento e identificación. La maleza fue identificada por criterios morfológicos. El patógeno se identificó mediante criterios morfoculturales de 100 conidios utilizando el software AxioVision Release 4.5. La purificación de los aislados se realizó mediante punta de hifa en PDA. Macrophoma sp. fue identificado en la maleza $C$. album con conidios elipsoidales a subglobosos, de 18,21 $\mu \mathrm{m}$ de largo y 2,56 $\mu \mathrm{m}$ de ancho. Por lo tanto, se recomienda una investigación futura de este patógeno y huésped.

Palabras clave: maleza; hongo; mancha foliar; conidios; micoherbicida.

Recibido: 09-09-2020.

Aceptado: 30-09-2020. 


\section{INTRODUCTION}

Mycoherbicides are formulations of plant pathogenic fungi that kill unwanted plants (USDA, 2020). Unlike chemical herbicides, which are made in factories, applied to plants and then degraded, mycoherbicides can be considered as living factories of chemicals, always ready to kill and prevent the growth of others plants (Jeremy, 2005). Weed account for more than $30 \%$ of total losses caused by all the pests (Gadermaier et al., 2014). A considerable number of plant pathogens have been studied for possible use in weed control and some have been shown to be virulent enough to control weed species and compete commercially with chemical herbicides. However, most weed pathogens are not useful in their wild form because they are not sufficiently host specific or virulent (Sands, 2009). C. album is the best example of herbicide resistance, as it has become resistant to synthetic herbicides (Aper et al., 2014; Nawaz et al., 2016) Barton 2005 mencionated such Colletotrichum, Phoma, Sclerotinia, Alternaria, Fusarium and Puccinia as bioherbicide candidates. New groups of phytopathogens are being integrated into the control of weeds such as bacteria and viruses, some are already available in the market (Harding and Raizada, 2015). Dagno et al. (2012) mentioned 15 available mycoherbicides. Aneja et al. (2013) integrates two making a total of 17 mycoherbicides on the market.

Phytopathogenic fungi in C. album are: Cercospora dubia (Riess) Wint., Dothiorella chenopodii Ahmad., Eutypella russodes (Berk. \& Br.) Berl., Leptosphaeria gallicola Sacc., Metasphaeria ambigua (Dur. \& Mont.) Sacc., Peronospora effusa (Grev.) Rabenhorst., Peronospora variabilis (Gaeumann) Mitteil., Phoma chenopodii Ahmad., and Phoma herbarum West. (Ahmad et al., 1997), Peronospora variabilis (Frinking and Linders, 1986), Ascochyta caulina (Evidente, 2000; Vurro et al., 20 01; Pacciolla et al., 2016), Alternaria alternata Nees (Siddiqui, 2009), Alternaria japónica Groves and Skolko (Dutta, 2015), Drechslera rostrata Leonard (Akbar et al., 2017) Fusarium equiseti (Corda) Saccardo (Jiang, 2019). Due to the previously mentioned, the objective this research was identify the fungi associated with the $C$. album leaf spot.

\section{MATERIAL AND METHODS}

\section{Sampling}

Sampling was performed on August, 2017 at Universidad Autonoma Agrarian Antonio Narro ( $\left.25^{\circ} 21^{\prime} 30.7^{\prime \prime} \mathrm{N} 101^{\circ} 02^{\prime} 20.8^{\prime \prime} \mathrm{W}\right)$. Ten weed plants of the Chenopodiaceae family with signs and symptoms of the disease (pycnidia and a yellow halo on the leaves) were cut and taken to the phytopathology laboratory.

\section{Identification of the weed $C$. album}

The identification of the weed plants of the Chenopodiaceae family at the species level was done using the taxonomic keys of Villareal (1983) and Vibrans (2011).

\section{Insolation and purification}

Cuts of leaves of diseased and healthy tissue approximately $1 \mathrm{~cm}$ length y $0.3 \mathrm{~cm}$ width, disinfected with $2 \%$ hypochlorite for $1 \mathrm{~min}$, and washed with distilled water (three times), 4 sections were placed equidistant per Petri dish with PDA with 10 replicates, and kept at $25{ }^{\circ} \mathrm{C}$ for $168 \mathrm{~h}$. The purification of the isolates was performed by hypha tip in PDA, which were stored at $4{ }^{\circ} \mathrm{C}$.

\section{Identification of Macrophoma}

Identification was performed whit a microscope using AxioVision Release 4.5 software (ZEISS, 2020), based on the characteristics of the mycelium, color and shape of the colony, color, length and width of 100 conidia, following Barnett and Hunter 2006.

\section{RESULTS AND DISCUSSION}

Weed Chenodopium album was identified and the presence of the phytopathogenic genus Macrophoma (Sacc.) Berl. and Voglino, was found. Mycelium brown-brown, septate, aerial and branched, pycnidia black and subglobose. Microscopically: Conidia, simple, ellipsoidal to subglobose, of $18.21 \mu \mathrm{m}$ length and $2.56 \mu \mathrm{m}$ width (Figure 1), results that agree by Barnett and Hunter, 2006 report. Stem black spot is a disease caused by Macrophoma sp. (FAO, 2020) and in severe attacks the incidence percentages can reach $30-100 \%$, in this research the incidence was $100 \%$. This fungus requires certain environmental conditions that favor its development, such as a one to two-week dry period before developing (Sánchez et al., 1991, ANAVMP, 2020) and the climate in the study area was warm $35-38{ }^{\circ} \mathrm{C}$. In controlled environment studies Macrophoma sp was pathogenic for the genus Amaranthus and the closely related genus Celosia (Chin, 1995). The impact of plant disease is determined by a tripartite interaction involving the host the pathogen and the environment (Agrios, 1988). Disease development can be constrained by various plant, pathogen and environmental factors with low virulence of the pathogen and fastidious environmental conditions the two major biological constraints (Watson and Wymore, 1990). However, Macrophoma causes diseases in importants crops as guava (Psidium guajava L), corn (Zea mays L.), tea (Camellia spp.), grape (Vitis vinifera L.), mango (Mangifera indica L.), berries (Rubus fruticosus L., Rubus idaeus L., 
Fragaria L.) among other crops. Phoma macrostoma was pathogenic to many dicotyledonous plant species, but nonpathogenic to monocots (Bailey et al., 2011) pathogen has a good potential as mycoherbicide in Parthenium weed. (Kaur and Kumar, 2019). Cimmino et al. (2013) reported that Phoma chenopodicola as bioherbicide in C. album, Cirsium arvense, Setaria viridis, Mercurialis annua and Annual mercury. Qing-yun et al. (2019) reported Aureobasidium pullulans as mycoherbicide in $C$. album, pathogen of the class Dothideomycetes, same that Macrophoma. There are numerous Phoma-like phytopathogenic fungi that are phytotoxin-producing. Todero et al. (2018) reported that combining adjuvants with culture filtrate of Phoma sp. showed phytotoxic efficiency against Bidens pilosa L., Amaranthus retroflexus L. and Conyza canadensis L. Brun et al. (2016) reported that metabolites produced by submerged fermentation of Phoma sp. presented activity in pre-emergence, post-emergence, and detached leaves of Cucumis sativus L. and Sorghum bicolor L. Mönch and it could be an alternative in the future for weed control.
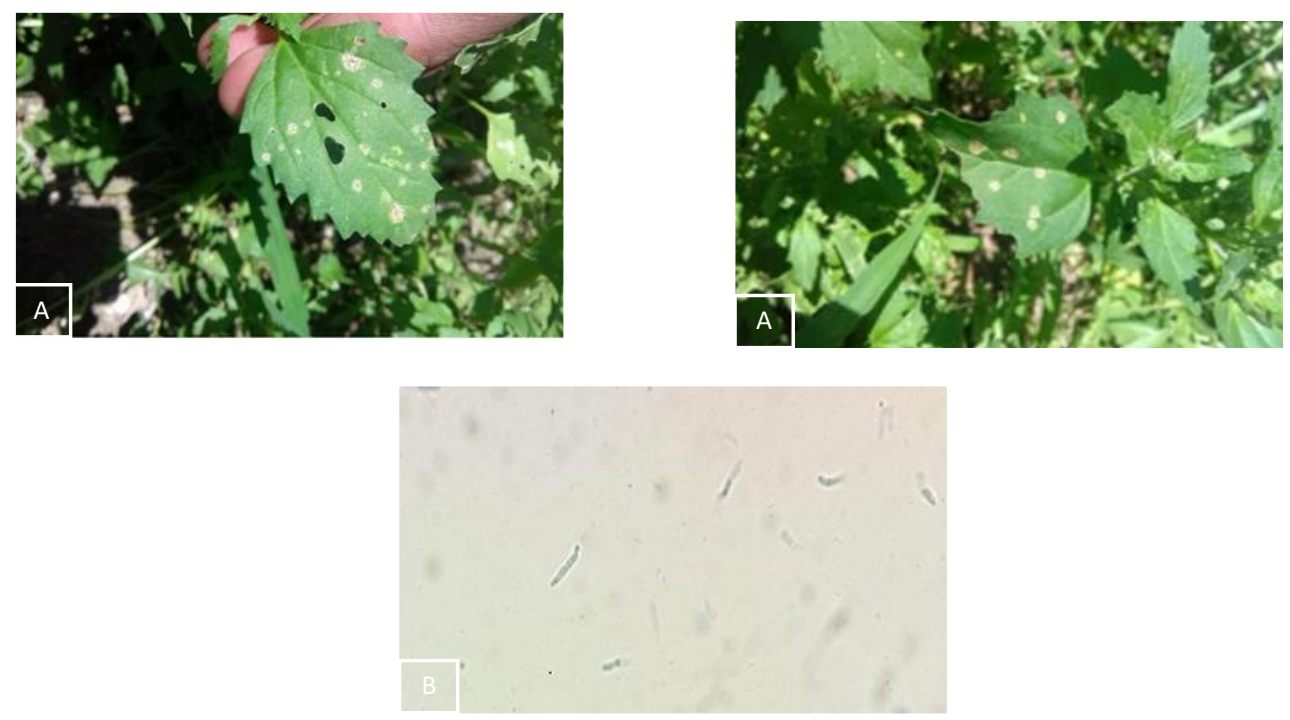

Figure 1. A) C. album plants with symptoms and symptoms, B) Macrophoma sp. conidia.

\section{CONCLUSION}

Macrophoma sp. was identified damaging the weed $C$ album whit conidia, ellipsoidal to subglobose, of $18.21 \mu \mathrm{m}$ length and $2.56 \mu \mathrm{m}$ width. Therefore a future investigation of this pathogen and host is recommended.

\section{BIBLIOGRAPHIC REFERENCES}

Agrios, G.N. 1988. Plant Pathology. 3 ed. Academie Press, Inc., San Diego, CA. 803 pp

Ahmad, S.; Iqbal, S.H.; Khalid, A.N. 1997. Fungi of West Pakistan. Mycological Society of Pakistan, Department of Botany, University of the Punjab, Lahore 54590, Pakistan.

ANAVMP - Sistema Nacional Argentino de Vigilancia y Monitoreo de Plagas. 2020. Macrophomina phaseolina. Consultado 19 oct. 2019. Disponible en:

https://www.sinavimo.gov.ar/plaga/macrophominaphaseolina

Akbar, M.; Iqbal, MA.; Khalil, T. 2017. Isolation and characterization of natural herbicidal compound from Drechslera rostrata. Planta daninha 35: e017163780

Aneja, K.R.; Kumar, V.; Kumar, P.J.; et al. 2013. Potential Bioherbicides: Indian Perspectives. En Salar R.K et al. (ed.), Biotechnology: Prospects and Applications, Springer. India.

Aper, J.; De Cauwer, B.; De Roo, S.; et al. 2014. Seed germination and viability of herbicide resistant and susceptible Chenopodium album populations after ensiling, digestion by cattle and manure storage. Weed Res. 54: 169-77.

Bailey, KL.; Pitt, WM.; Falk, S.; et al. 2011. The effects of Phoma macrostoma on nontarget plant and target weed species. Biological Control 58(3): 379-386.
Barnett, L.H.; Hunter, B.B. 2006. Illustrate genera of imperfect fungi. Minnesota, The American Phytopathology Society Press. 200-220 pp.

Barton, J. 2005. Bioherbicides: All in a day's work for a superhero. What's New in Biological Control of Weeds 34: 4-6.

Brun, T.; Rabuske, JE.; Todero, I.; et al. 2016. Production of bioherbicide by Phoma sp. in a stirred-tank bioreactor. 3 Biotech 6: 230.

Chin, A. 1995. Evaluation of Macrophoma sp. as a potential mycoherbicide for the control of Amaranthus retroflexus $\mathrm{L}$. (Redroot Pigweed) Master of Science. Departmenl of Plant Science. Macdonald Campus of McGiII University. Bellevue, Québec, Canada. 49 pp.

Cimmino, A.; Andolfi, A.; Zonno, MC.; et al. 2013. Chenopodolin: a phytotoxic unrearranged ent-pimaradiene diterpene produced by Phoma chenopodicola, a fungal pathogen for Chenopodium album biocontrol. Journal of Natural Products 76(7): 1291-1297.

Dagno, K.L.R. 2012. Present status of the development of mycoherbicides against water hyacinth: successes and challenges. Biotechnol. Agron. Soc. Environ. 16(3): 360-368.

Dutta, W.; Durga, R.; Puja, R. 2015. Molecular characterization and host range studies of indigenous fungus as prospective mycoherbicidal agent of water hyacinth. Indian Journal of Weed Science 47: 59-65. 
Evidente, A.; Andolfi, A.; Vurro, M.; et al. 2000. Trans-4aminoproline, a phytotoxic metabolite with herbicidal activity produced by Ascochyta caulina, Phytochemistry 53(2): 231-237.

Gadermaier, G.; Hauser, M.; Ferreira, F. 2014. Allergens of weed pollen: an overview on recombinant and natural molecules. Methods 66(1): 55-66

FAO - Food and Agriculture Organization. 2020. V. Tecnología del cultivo. Enfermedades causadas por hongos. Disponible en: http://www.fao.org/tempref/GI/Reserved/FTP_FaoRlc/old /prior/segalim/prodalim/prodveg/cdrom/contenido/libro 01/Cap5.htm

Frinking, H.D.; Linders, E.G.A. 1986. Una comparación de dos patosistemas: mildiú velloso en Spinacia oleracea y en Chenopodium álbum. Holanda J. Plant Pathology 92: 97-106.

Harding, D.; Raizada, M. 2015. Controlling weeds with fungi, bacteria and viruses: A review. Frontiers in plant science 6: 659.

Jeremy, B. 2005. El micoherbicida está de vuelta. El congreso de Estados Unidos declaró la guerra biológica a Sur América en una nueva propuesta. Disponible en: http://www.mamacoca.org/docs_de_base/Fumigas/Bigwoo d_el_micoherbicida_esta_de_vuelta.htm

Jiang, WY.; Shen, ZB.; Cai, YN.; et al. 2019. Primer informe de la mancha foliar de Chenopodium album causada por Fusarium equiseti en China. Disponible en: https://apsjournals.apsnet.org/doi/10.1094/PDIS-06-191131-PDN

Kaur, M.; Kumar, V. 2019. Studies on various histopathological parameters to evaluate the biological control potential of Alternaria macrospora MKP1 against Parthenium weed. Department of Microbiology, Kurukshetra University Kurukshetra, Haryana, India, 136119.

Nawaz, A. 2016. Farooq M. Manejo de malezas en sistemas de producción de conservación de recursos en Pakistán. Crop Protec. 85: 89-103.

Paciolla, C., De leonardis, S., Zonno, M., et al. 2016. Antioxidant response in Chenopodium album elicited by Ascochyta caulina mycoherbicide phytotoxins. Phytopathologia Mediterranea, 55(3): 346-354.
Qing-yun, G.; Liang, C.; Hai-xia, Z.; et al. 2019. Herbicidal activity of Aureobasidium pullulans PA-2 on weeds and optimization of its solid-state fermentation conditions. Journal of Integrative Agriculture 19(1): 173-182.

Sánchez, E.M.; Espitia, R.E.; Osada KS. 1991. Etiología de la mancha negra del tallo (Macrophoma sp.) en el Amaranto (Amaranthus sp.). p. 67. En: Primer Congreso Internacional del Amaranto. Septiembre 22-27. Oaxtepec, Morelos, México.

Sands, D.C.; Pilgeram, A.L. 2009.Métodos para seleccionar agentes de biocontrol hipervirulentos de malas hierbas: por qué y cómo. Pest Manag. Sci. 65: 581 - 587.

Siddiqui, I.; Rukhsana, B.; Arshad, J. 2009. A new foliar fungal pathogen, Alternaria alternata isolated from Chenopodium album in Pakistan. Pakistan Journal of Botany 41: 1437-1438.

Todero, I.; Confortin, T.C.; Soares, F.; et al. 2018. Concentration of metabolites from Phoma sp. using microfiltration membrane for increasing bioherbicidal activity, Environmental Technology 40(18): 2364-2372

USDA- Departamento de Agricultura de los Estados Unidos. 2020. Biblioteca Nacional de Agricultura. Disponible en: https://agclass.nal.usda.gov/mtwdk.exe?k=2007es\&l=115\& $\mathrm{w}=45192 \& \mathrm{~s}=5 \& \mathrm{t}=2$

Vibrans, H. 2011. Taller de identificación de malezas. Disponible en: https://es.scribd.com/document/431221502/Taller-deIdentificacion-de-Malezas

Villareal, J.A. 1983. Malezas de Buenavista, Coahuila. México: Universidad Autónoma Agrícola Antonio Narro, Buenavista, Saltillo, México, 271 pp.

Vurro, M.; Chiara, ZM.; Evidente, A.; Andolfi, A.; PAsquale, M. 2001. Enhancement of efficacy of Ascochyta caulina to control Chenopodium album by use of phytotoxins and reduced rates of herbicides. Biological Control 21(2): 182-190

Watson, AK.; Wymore, LA. 1990. Identifying limiting factors in the biocontrol of wecds. pp. 305-316 ln Baker. R.R and Dunn. P.E. (eds.), New Directions in Biological Control: Alternatives for Suppressing Agricultural Pests and Diseases. Alan R. Liss Inc., New York, NY.

ZEISS, 2020. Programa AxioVision. Disponible en: https://www.microshop.zeiss.com/en/us/system/software+axiovisionaxiovision+pro gram-axiovision+software/10221/ 